\title{
Silent "Night of Madness"? \\ Light, Voice, Sounds, and Space \\ in the Illenau Asylum in Baden \\ between I842 and I9IO
}

Kai Sammet

The Illenau asylum in Baden was built between 1837 and 1842 according to plans by Christian Friedrich Wilhelm Roller (I802-I878) near the town of Achern on the edge of the northern Black Forest. It was the first institution specifically designed for the mentally ill in the Grand Duchy of Baden and was meant to accommodate around 300 patients. Prior to its construction, Roller wrote a kind of pamphlet for the authorities in I83I in which he explained his views. Die Irrenanstalt nach allen ihren Beziehungen is a compendium of psychiatric care around 1830 in which Roller frequently refers to theories and views of leading psychiatric theorists.

In the following I will cover only a few aspects related to light, noises, and space at the Illenau. ${ }^{\text {I }}$ Further studies would then have to compare different institutions and writings.

First, we can ask the question: How bright was it at night at the Illenau? Outside? Inside? Was it a silent "night of madness" (Roller I83I: VII-VIII)? Outside it was probably mostly dark. But what does that mean? What lightscape can we imagine? This cannot be said with certainty. But photographs allow us to make conjectures. 


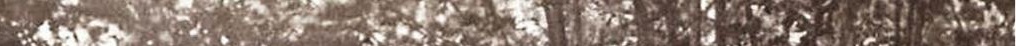



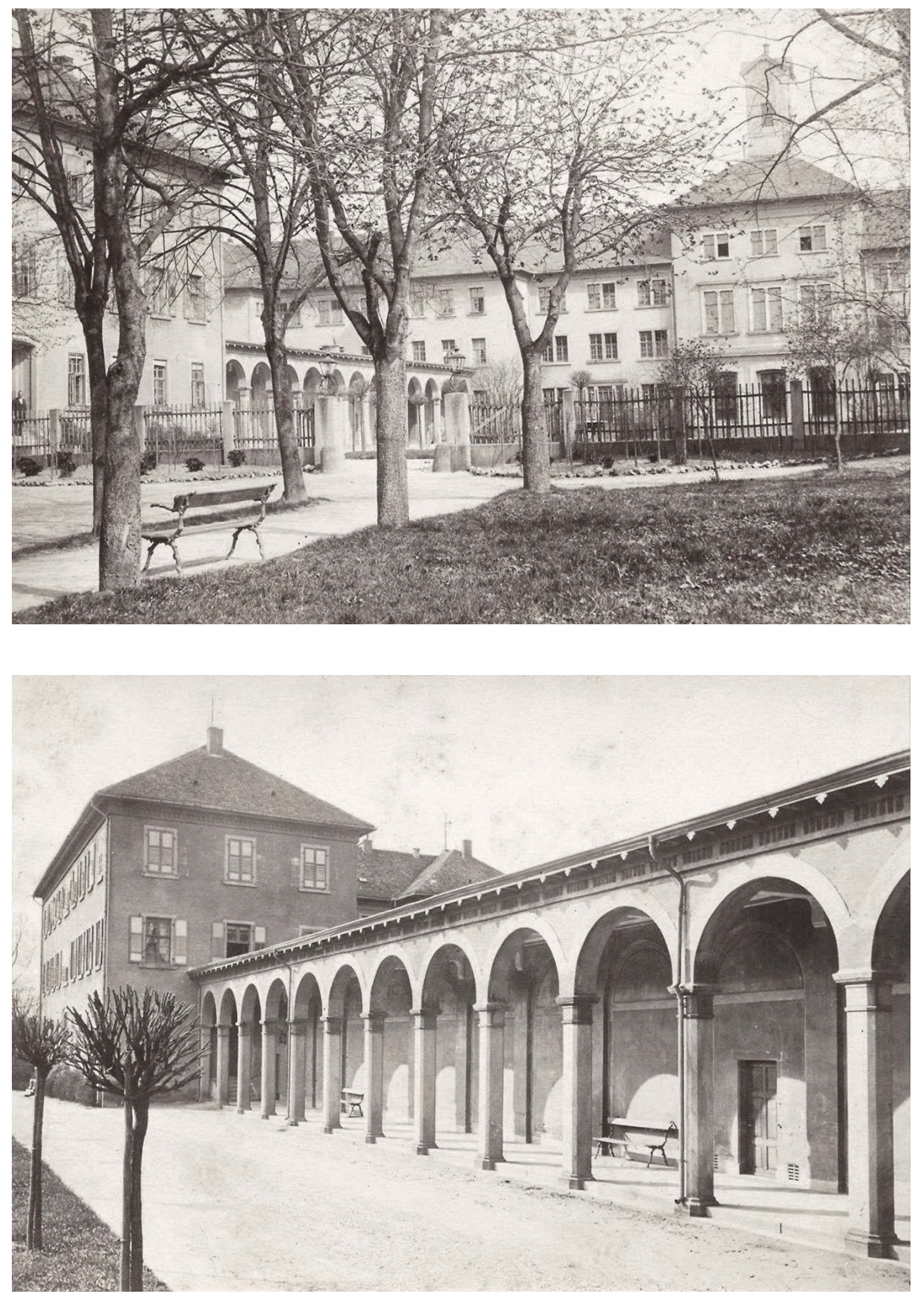

Fig. 2: Main entrance, GLA Karlsruhe 69 Baden, collection $1995 \mathrm{FI}$ no. 78, 14, image I

Fig. 3: Arcades, GLA Karlsruhe 69 Baden, collection $1995 \mathrm{FI}$ no. 78, 18, image 1 
And inside? What artificial light sources existed in the rooms? It was not until I892 that electric light was introduced (Schüle I9I0: 7). Previously there were oil lamps and later kerosene lamps. In the sequence of artificial light sources from candles to oil lamps, kerosene, gas, and electricity (Schivelbusch 2004), gas was never used at the Illenau. Roller was of the opinion that the danger of fire was too great (Roller I83I: I49). How bright the light sources were is unclear. A candle has an intensity of one candela. Other light sources have many multiples of one candela, but because the intensity of premodern lighting often depended on the quality of the fuel, it is impossible to make precise statements. It is difficult to estimate how bright certain oil lamps were. It is also unclear how many light sources there were in a room, where they were, and whether the lighting was moveable or fixed to the wall. Here, too, a photo of the "ladies' salon" from I876 offers a clue (fig. 4). No light sources are visible on the walls. A lamp is placed on top of a chest of drawers. It does not seem to be attached to it. Was it brought to the little table in the middle of the room in the evening - a soft, cone-shaped light for chatting and sewing?

What other indications are there? Corridors were to be illuminated all night, and dormitories were to be lit with a faint "shimmer" (ibid.: I49). Due to the risk of fire, the patients were not allowed to have light. In that case, perhaps there would have been light in the corridors, but the patients would have lain in the dark all night in the dormitory, briefly illuminated by the night watches on their rounds? And what can we imagine "faint shimmer" to mean? What effect did this have?

The perception of light as bright, faint, or glaring is historically contingent (Schivelbusch 2004). According to recent spatial sociological theory, spaces exist only as they are read and perceived. Spaces are relational. Atmospheres are important in order to understand them (Löw 200I). What kind of light atmosphere was there at the Illenau, and how did the patients, doctors, and staff perceive it? This, too, is difficult to precisely discern. But there is another indication of how part of the lightscape at the Illenau could have been. The doctor Oscar Mahir, who traveled through Belgium, France, the United Kingdom, and Germany in the early I840 to see mental asylums, complained in I846 that the lighting at the Illenau was "too dim, which has an adverse effect on the mood of the patients" (Mahir I846: I78).

Altogether, it can be supposed that night at the Illenau was a preindustrial, rural night. Dark night around the asylum, enclosed in itself, its isolation; in the rooms light cones rather than a broadly scattered light. In the dormitories is darkness, in the corridors the lighting is difficult to discern, but it is likely dim. Is that all that can be said about light at the Illenau? No, but the following also remains fragmentary. 


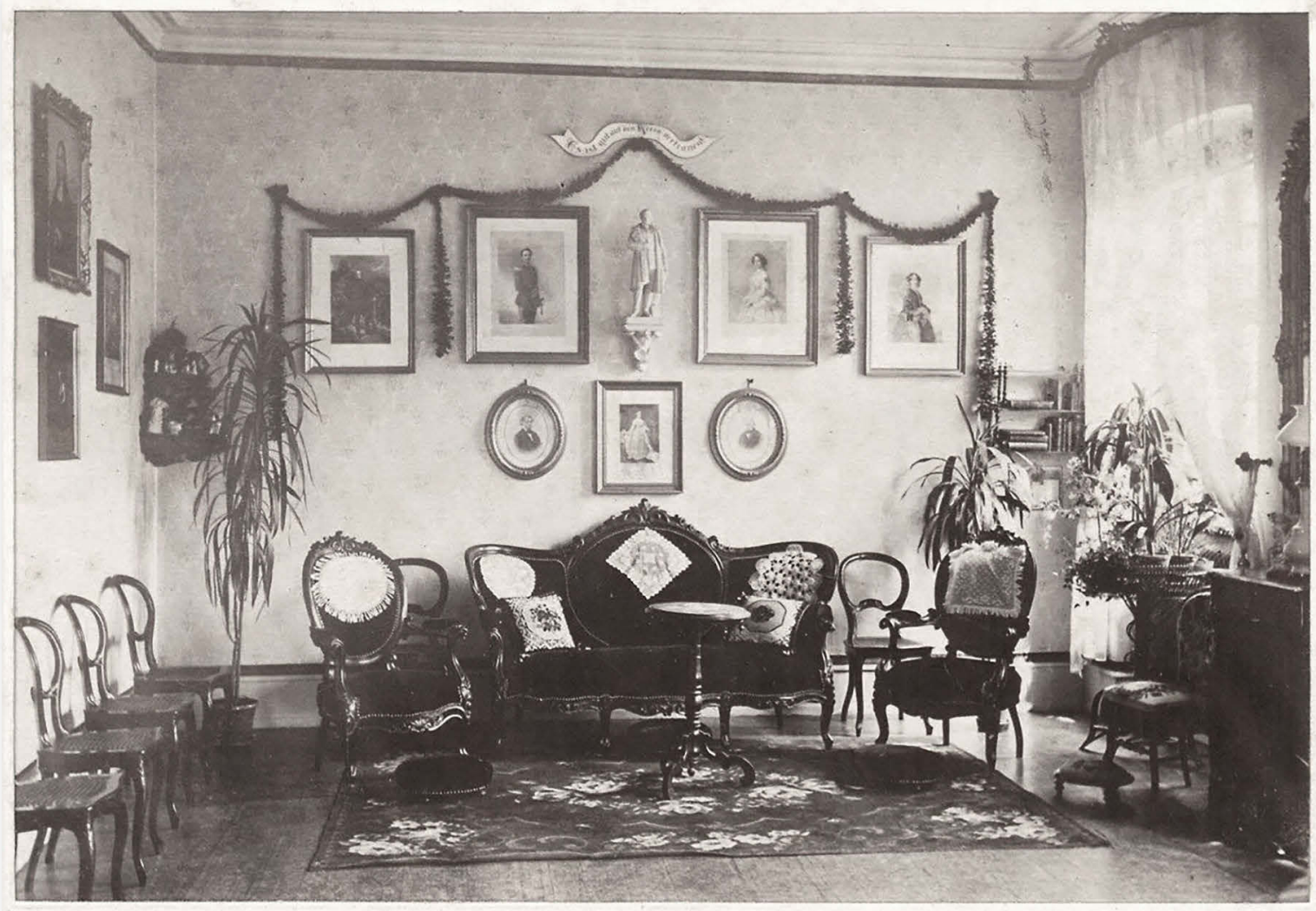

Light is not among the under-theorized concepts, neither in science nor in philosophy, religion, superstition, or art history. Almost every aspect has been covered in literature. There are nuanced differences between terms such as light metaphor, light metaphysics, light symbolism: ontologically, theologically, epistemologically, mystically, in terms of natural philosophy (cf. Beierwaltes/Bormann I980; Beierwaltes I980). I will limit myself to just a few aspects and will discuss them only selectively. I am mainly interested in light as a medium of connection and communication. What follows are some anecdotes and excerpts. 


\section{From Freud to Roller to Bresson: Anecdotes and Fragments}

The first anecdote is from Freud (1942: 126). A three-year-old boy asks from a dark room: "Aunt, talk to me; I am afraid because it is so dark." The aunt, in the room next door: "What good will that do you? You can't see me." The boy: "It doesn't matter. When someone speaks, it gets light."

The next four passages are from Roller's book Die Irrenanstalt nach allen ihren Beziehungen (I83I) and from a publication about the Illenau from I865. These discuss (I) the patients' clothes: "every patient" received two sets of summer and winter clothing, "avoiding any sense of a uniform by using different materials, colors, and cuts" (Roller I83I: I26). They also discuss (2) walking areas. Dense bushes were taboo. Better choices were "lawns decorated with flowers and shaded by avenues of linden trees or acacias" (ibid.: II4). In $\$ 89$ of the house rules from 1865 , it is emphasized (3) that the institution must always be kept tidy, and "especially" the corridors must "not be blocked" (Direction I865: II8). Then it describes (4) the therapeutic effect of the mental asylum. The patients are confused; "law and order, which is no longer dictated by his own reason, must be impressed from the outside, ... become the property of the patients as if reflected according to optical laws" (Roller I831: I6I-I62).

The following three passages are from Notes on the Cinematographer by the filmmaker Robert Bresson. They discuss the eye and/or gaze. Bresson speaks of the "ejaculatory power of the eye," then goes on to say: "Two people who look into each other's eyes do not see their eyes but their gazes." And finally: "Putting together a film means connecting people to each other and to things through gazes" (Bresson 2007: 22).

What connects these passages? Although in different ways, they all deal with light. Better: different connotations of light are evoked.

What is light? And what does it have to do with "materialities"? In the "material turn" in historiography (I) artifacts, things that are made, and/or naturally existing, non-living objects are the focus of attention (Derix et al. 2016). (2) Then it is asked how human (knowledge) practice is incorporated in them. (3) It is asked if/how objects are assigned a kind of actor status ("actant" [Latour 2007]) within practices. It also deals with "immaterial" properties of material, objects, their semantics and knowledge technologies. Almost no other "material" embodies this entanglement of the material and the immaterial better than light.

In reflections on the structure and space of mental asylums, light and the illumination of patient rooms, corridors, and functional rooms play an important role. 
For instance, windows (transparent media for light) and their size and construction have been discussed in depth (cf. e.g. Roller I83I: 99-IO2). But this is not just meant in a concretely material sense. Light has long been metaphorically linked to knowledge, divinity, reason, while darkness stands for chaos, unreason, insanity.

Concepts of light and brightness are also etymologically associated with saying, with revealing in speech. Light and speech are closely connected. Freud's threeyear-old shows this. Interestingly, around 1800 the voice ${ }^{3}$ of the psychiatric physician played an important role in views on therapy for the mentally ill. Darkness, on the other hand, stands for silence as the metaphor for unreason. But while the absence of speech is negatively connoted, another form of noiselessness, silence, is seen positively as a possible therapeutic practice (for example, in a dark room).

Etymologically, light is also related to spatial concepts, which results in complex links between illumination as a material phenomenon and, for example, the illumination of spaces.

In the above passages, light now appears metaphorically, sometimes physically and materially; sometimes it is about what actions light makes possible - seeing and looking - and sometimes it is about architectural lighting.

\section{What Do These Passages Mean?}

Let us first turn to Freud's anecdote about the three-year-old boy. Alone in the dark, it is the same: It is the original model of devastating abandonment in humans as animals that form bonds (Strauß 20I4; Lengning/Lüpschen 20I2). The three-yearold is without bonding, isolated, separated from the people he has bonded with: isolation, communication vs. non-communication, the gaze, supervision, observation, silence, voice. These are, as already indicated, central phenomena in the theory of the mental asylum. In Freud's three-year-old the most important sense organ is denied bonding. Consider how children's eyes communicate with their mothers in unfamiliar situations, how they reassure themselves with a glance (whether the smiling stranger in the bus is trustworthy or not). The boy does not see his aunt. There is no light from her, since no gaze comes from her. Bresson: "Two people who look into each other's eyes do not see their eyes but their gazes." If he saw her, he would not be alone. Then he would have confidence. What does he do? He establishes a bond with the aunt through the voice. He brings her to him through 
talking, so to speak; he makes her present. Now her body is there, even though he is not there. The aunt believes that only seeing will help, only face-to-face contact will take away his fear - he will not gain the light, the sight of her presence. The boy knows better. Speaking turns on the light.

Now I will turn to Roller's discussion of clothing. The house rules call for colors. Colors are the wavelengths of the spectrum that are visible to our eye. This is the physical and material side. But why should there be colors in the asylum? There were discussions about whether or not patients should wear uniform-like clothing (Roller I83I: 126). Roller advocated for individuality. Colors in general (see the flowers) offer a friendly sight. What is a "friendly sight"? Apparently, something that connects the eye and the object in a certain way - friendliness. This connection between the eye and the object can already be found in Plato's analogy of the sun, which ties together the sun, eye/seeing, visibility of objects, and light. The sun-like eye can see because there is light; light connects the eye and objects and truth. On the one hand, then, the gaze is an emanation of light; light makes it possible to see; thus it produces seeing.

Now, however, seeing something is always determined by the one who sees this object: each individual sees things differently. Thus, the gaze of the one who is looking also has a "producing" aspect. This is Bresson's "ejaculative" power. Taking this "phallic" metaphor seriously means not only throwing out, but, in connection with the sexual connotation, engendering. A gaze engenders a connection between the eye and what is seen - and in this regard an object can be "friendly" (for why this is so, see below). To understand the next passage from Roller's book, which deals with the walking areas, we must look at pictures.

We are looking at the Illenau, in the foreground two building ensembles, separated by an avenue (fig. 5). These are farm buildings (stables, among other things). In the background the asylum itself. In front of the left building complex of the asylum are walking areas. We can see the plants. Nowhere do they run wild. It is a cultivated landscape created by human beings. The type of planting and thus the composition of the space is even clearer in figure 6 .

We are looking at the church and the interior of the asylum (we already saw this; on the left are the arcades again: cf. fig. 2 and fig. 3). Inside and outside, this landscape has been constructed. Inside is the well, around it bushes and trees; everything is loosely distributed. On the one hand, this is Enlightenment: creating anew according to human principles (Porter I99I; Reed 20I2). On the other hand, it is also the theory of the Earl of Shaftesbury (I67I-I7I3) of nature as a moral power. According to 


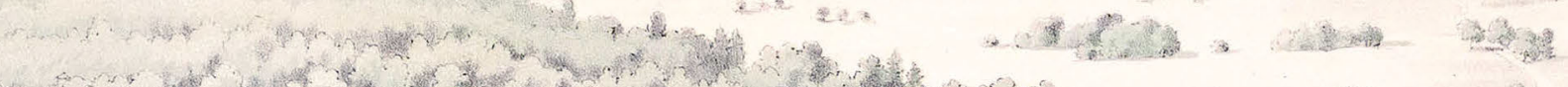

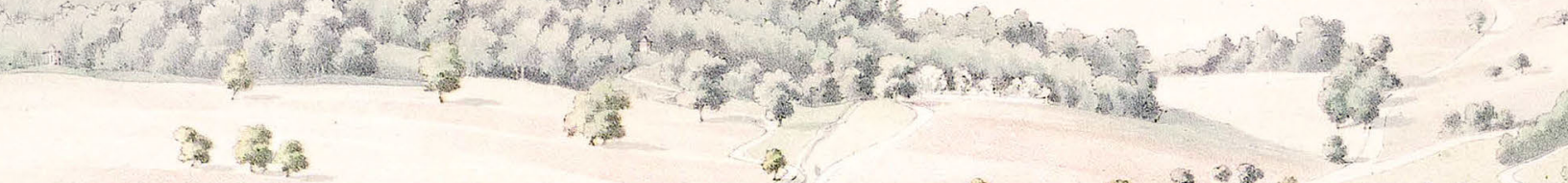

$x^{3}+\cdots+3$

$3+\beta$

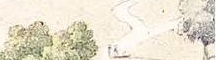

430 s.

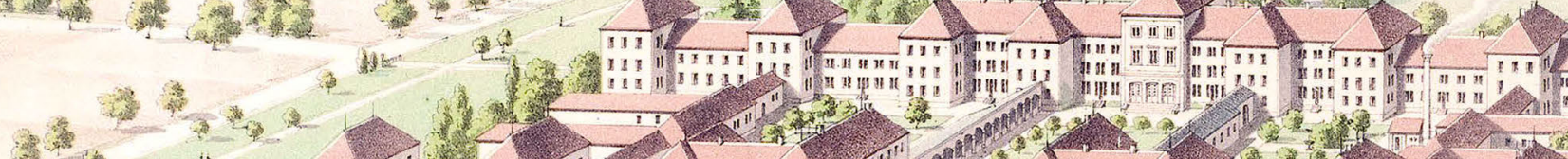

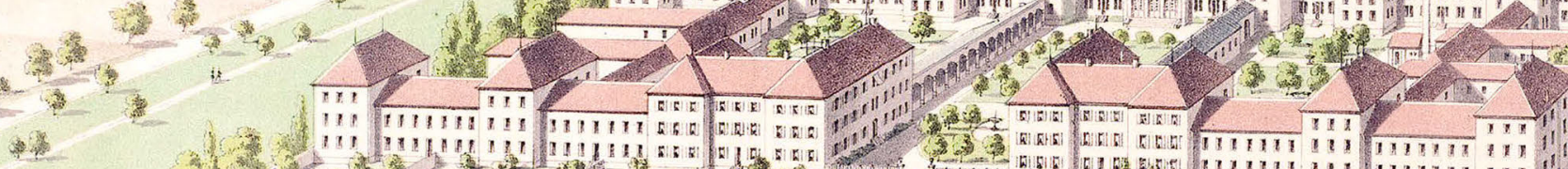

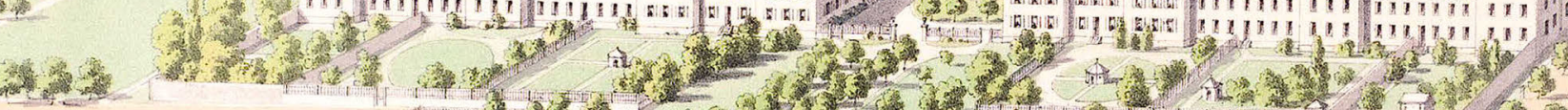

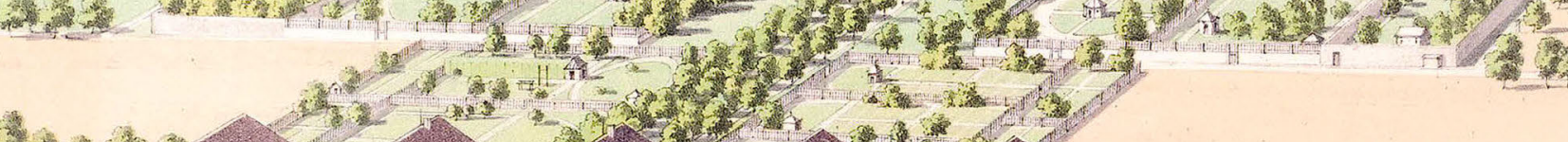

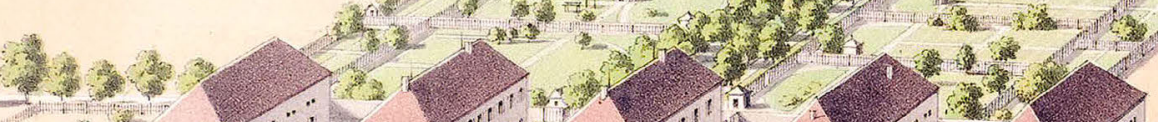

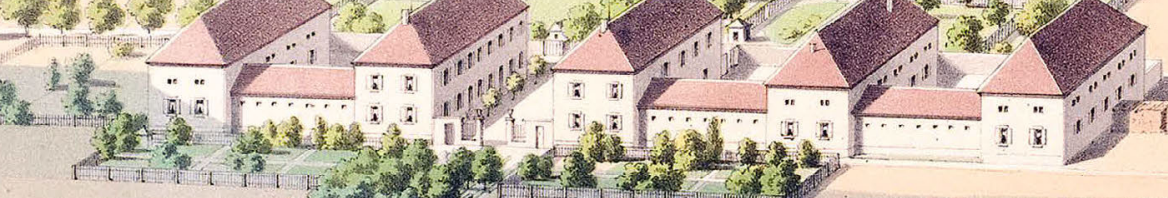
(4)

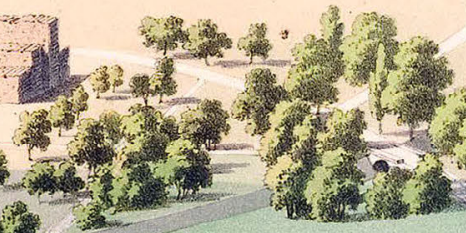


this theory, nature reflects the harmony of the cosmos; it is good, and so it is a moral power. It looks friendly; the sight of it is friendly. As beauty, it awakens morality in people (Klein 2003: 15-18). And what kind of cultural space is built there? With this approach to planting there is a play between light absorption by bushes and trees and the passage of light, and thus the gaze. Here a space made of shade, light, color, and the gaze has been built.

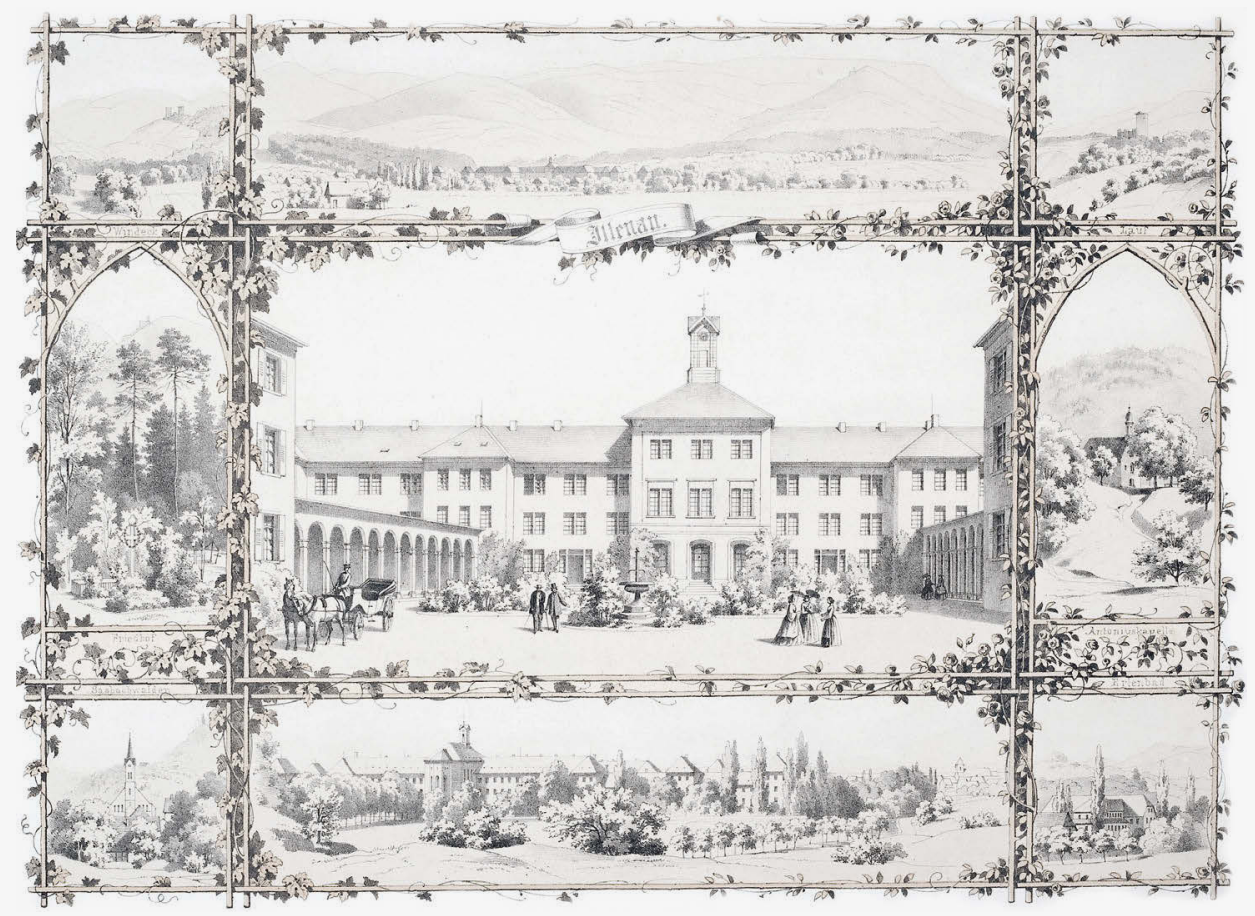


The light is not stopped by dense bushes like it is by a wall. This is important. Although Roller says the asylum needs an enclosure, meaning it must be separated and isolated in space as a separate space, he does not want a high wall as a means against escape attempts, because that would give the institution an "unfriendly, prison-like appearance" (I83I: II5). But how should escape attempts be prevented? Roller: "mainly through the living supervision" (ibid.). So again through the gaze, seeing through the medium of light. But Roller is also against dense bushes, because they make supervision more difficult. The patients must be visible - this requires not only light, but a lighting created by the construction of the space. Light then allows observation. Natural light is thus tamed on the one hand; on the other hand, it radiates, but it is also scattered, for example by leaves on a tree. In order not to seem too claustrophobic, living supervision is needed to walk around and observe. This must be accommodated by the construction of the asylum. It must be constructed so that "anything angular is avoided" (ibid.: 93). Light does not bend around corners. What is meant by this can be found in the third example: Corridors must not be blocked.

We are looking down the corridor of the women's section (fig. 7). Although there are many rubber plants here, the passageway itself is free. The visual axis is clear. Lighting through architecture. The light wanders through the straight corridor. This is why the passageway must not be blocked.

Finally, I come to the last passage from Roller's book mentioned above: The patient is confused; "law and order, which is no longer dictated by his own reason, must be impressed from the outside, ... become the property of the patients as if reflected according to optical laws" (ibid.: I6I-I62). This is a strange metaphor. But it shows again how closely reason/optics/light are linked together. The patient is confused, "thoughts and desires" (ibid.) ceaselessly wander around in his mind. Nothing is ordered; everything is somehow random. The element of the coincidental and ceaseless means a disregard for reason - and this, in turn, is identified with blindness in Plato's analogy of the sun (Plato I97I: 506c). The patient is able to see again when law and order cast light like in a mirror and from this mirror ("reflected") the rays of reason are cast into the mentally ill person and then law and order become the "property" of the patient. It is dark in the "night of insanity." The natural light of reason which is otherwise radiant in us is extinguished; now it is lit again by law and order. 


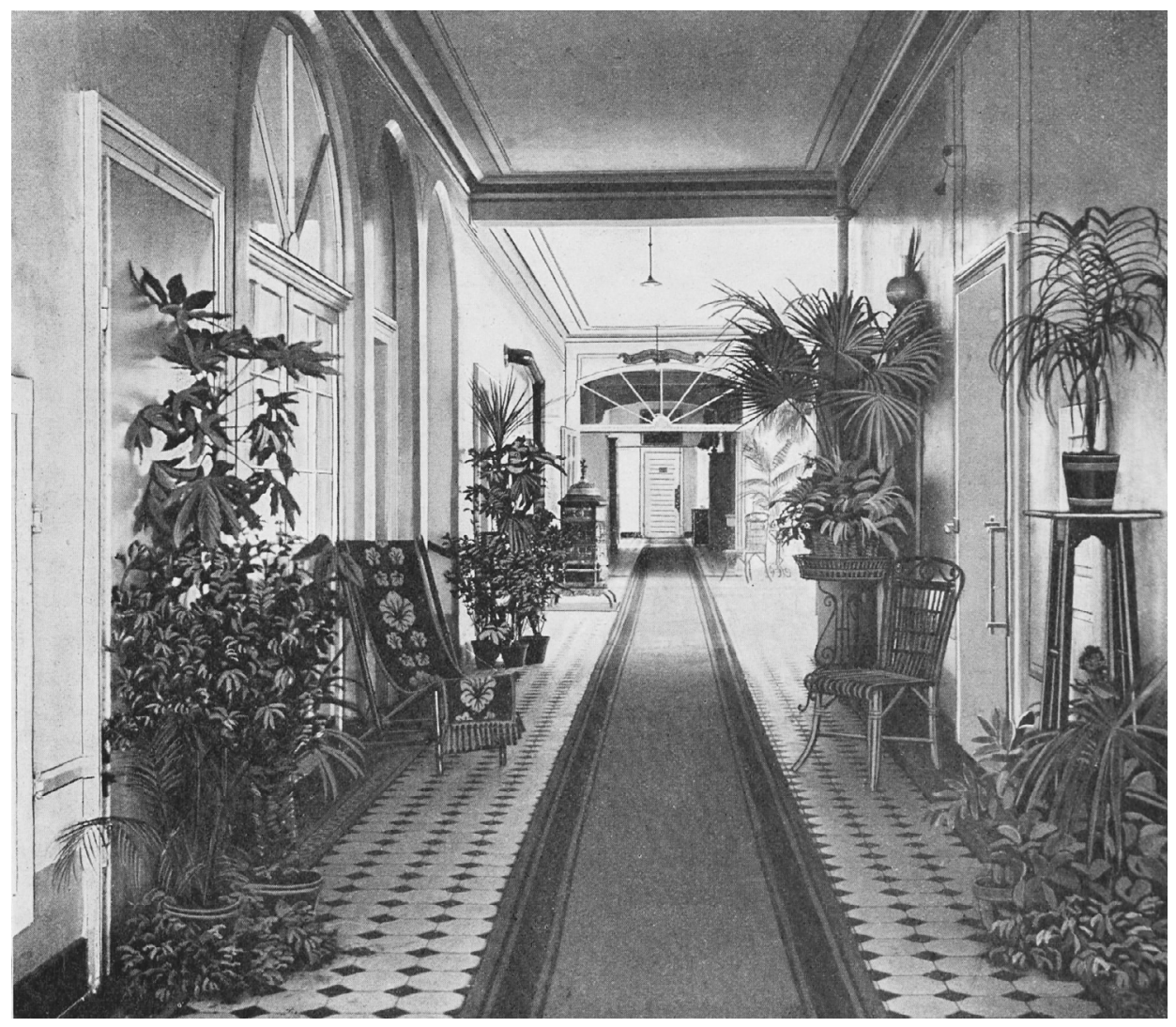

Light As Surveillance

Roller postulated: Only a newly built institution would fulfill the purposes of healing and care. Therefore, for the Illenau, the first asylum in Baden, existing building complexes (for example, a former monastery) would not be adapted. This, in turn, is a concept from the Enlightenment. The new must not be built into the old; the new must be created anew from the ground up. Only in a "suitable place" can "house rules and supervision" be carried out (Roller I83I: I8). Again, supervision and observation require a spatial order, which implies an order of light. We saw it in the bushes, in the corridor. Lighting through buildings or plants serves surveillance. 
Is this simply panoptism through architecture? Is light only a medium of surveillance and discipline? Surely, supervision is central to the asylum. There are many passages in Roller's book that not only give the impression of being about ensuring surveillance and discipline through constant visibility. For instance, Roller is against single rooms because "no supervision takes place" (ibid.: I06). Larger rooms make supervision easier. An attendant can sleep in them so that the patients are under (virtual) surveillance all night long (ibid.: I06-IO7). The patients are to eat together in the designated halls, where "complete supervision is possible. The doctor can easily supervise all the patients at this hour" (ibid.: I66-I67). Roller sees little value in the proposal to divide an institution into several small buildings, a pavilion system, since this would make "inner supervision difficult" (ibid.). In connected buildings, moreover, "internal communication" is easier (ibid.: 94). Does that mean (as is so often said) that "the asylum" is nothing but a disciplinary institution, here too and explicitly a "total institution" because the surveillance is "total" (Goffman 196I)? That would be an exaggeration. Furthermore, in Germany there was only one institution designed according to the architectural model of Jeremy Bentham: Erlangen, with a surveillance tower in the middle. This is partially evident in Roller's approach: nothing angular, the free corridor. However, it seems that the architecture was meant to promote a kind of mobile, flexible panoptism: "living supervision." And:

The supervision in the mental asylum must be general, must extend over everything and encompass the whole: the police, the farm buildings, as well as the symptoms of the disease; it is a joint duty, must be exercised from the first director to the last servant, so that everyone is watched by the one above him. Then it must be constant, must not be interrupted by any incident or time of day. It must continue through the night. (Roller I83I: I7I)

All this sounds like flexible panoptism with the main purpose of control. Foucault posits: "He who is subject to visibility and knows it takes over the coercive means of power and plays them against himself; he internalizes the power relationship ... ; he becomes the principle of his own submission" (Foucault 1992: 260). This is certainly intentional in (disciplinary) institutions. But Foucault offers no argument why this should be so. The vague concept of internalization obscures it. Why should people not be able to distance themselves from the gazes of others? Moreover, perhaps something other than control is meant by this. One can 
also interpret gaze/visibility differently: Freud's three-year-old does not want to be supervised; he wants to be protected. Roller wants a coherent structure because "internal communication" (emphasis mine; Roller I83I: 94) is possible in it, meaning connection. If the attendant sleeps in the hall, then he is present, maintains a connection. It remains undecided whether light is a disciplinary technology or a medium of communication. It is both at the same time.

\section{Other Aspects of Light}

There are other aspects that could support a different interpretation of the mental asylum as a mere disciplinary institution. Let us look at the natural light on Saturday, 2 September 1865 , for example. It is 5 a.m. in Achern. The day is dawning. It is time for the night attendants, "keepers of the sleeping, protectors of the houses, invisible observers and silent judges," 4 in 1865 two of them male and two female, at the Illenau, to wake the daytime attendants. Did anything particular happen at night? Perhaps someone died: "The dead are brought to the morgue in the silence of the night" (ibid.: 169). Perhaps someone became wild; mania expresses itself especially at night. Perhaps the doctor, who is supposed to do night rounds, was not present. If his body of reason is not there, the silence gives birth to monsters. The doctors must be present in the institution at all times; they must live in the institution. After all: "At every hour of the day and night they must be able to look after things and remain in constant contact with the institution." In this context, Roller quotes the French psychiatrist Jean Étienne Dominique Esquirol: "One has no real insight into insanity if one has not frequently observed the mentally ill during the night" (ibid.: 32I-322).5

And: Night and death are the same; the dead are not dead, they descend upon the living. Light dispels fear and chaos; the gaze of the physically present doctor dispels the darkness of mania. This is not supervision. It is magical and psychological thinking at the same time. The doctor is the embodiment of reason. If he is there, then there is light.

After the attendants, a bell wakes the patients, all at the same time. In the winter it is still dark. The bell is a central regulating noise in the institution. It separates day from night. Thus it is a light switch: with its sound, the sick come out of the isolation of their solipsistic, insane nights, out of their silent night of madness, into 
the community and thus communication and connection with everyone. Later the work begins - preferably in the field and in the garden, outdoors (ibid.: I87). In the winter, wood is chopped, some work in workshops, some even in the dark cellar, where often artificial light is necessary.

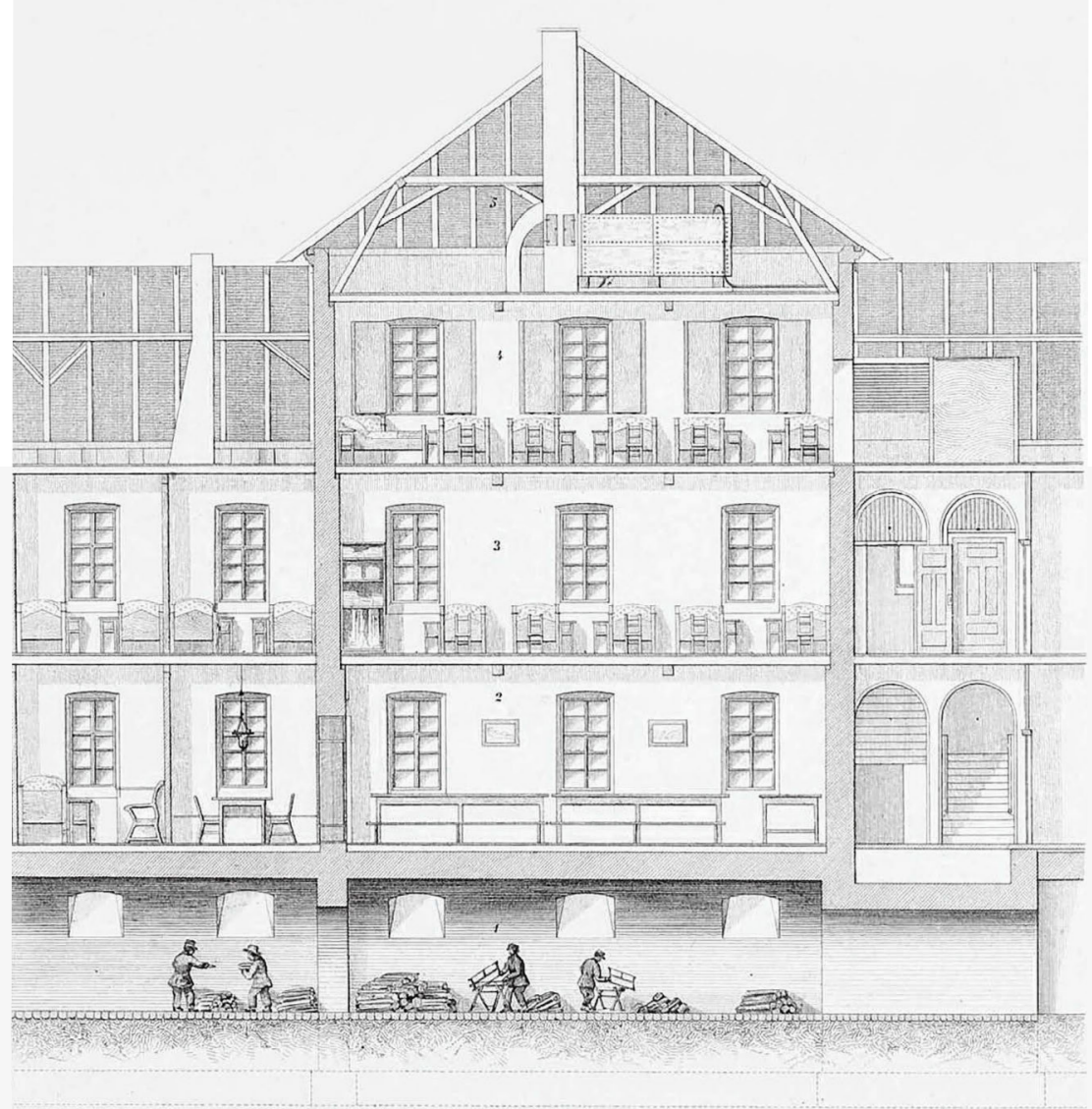

Fig. 8: Chopping wood in the cellar

(from: Direction 1865)

> Fig. 9: Geographical orientation of the Illenau

(from: Direction 1865) 
It seems trivial that the lighting conditions for individual patients were different depending on the season, day/night, weather conditions, indoors/outdoors. But if light were only a medium of panoptism, then the asylum would be like a high-security prison: glaring light 24 hours a day and/or constant exposure to the gaze. This is not the case; it is not just about control. At 9 p.m. the bell sounds: bedtime. With this last sound, the light is switched off, so to speak, and the patients wander back to the isolation of their sleep - in dark rooms.

Let us start the day again. The day is dawning. What is illuminated by the sun? In the morning the sun strikes the back parts of the institution at an angle, and in the evening the front parts. In I83I Roller preferred the main facade to be facing south (ibid.: 64). Here it is different. From Achern the road makes a curve and then straightens out; this is not a north-south orientation.

That may have been a pragmatic decision; several areas in Baden were visited before the construction. Or it is not so important. It is not just about the angle at

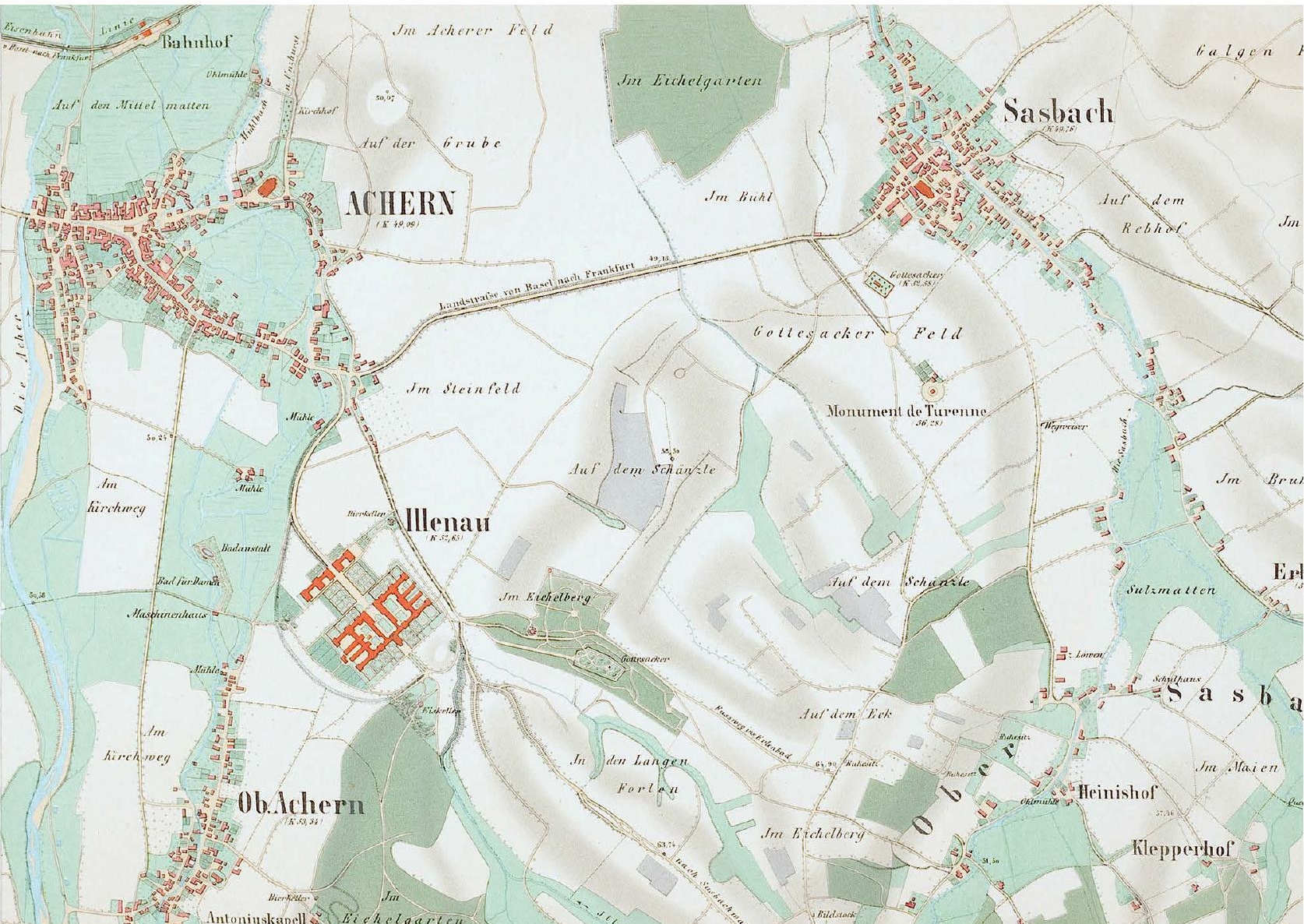




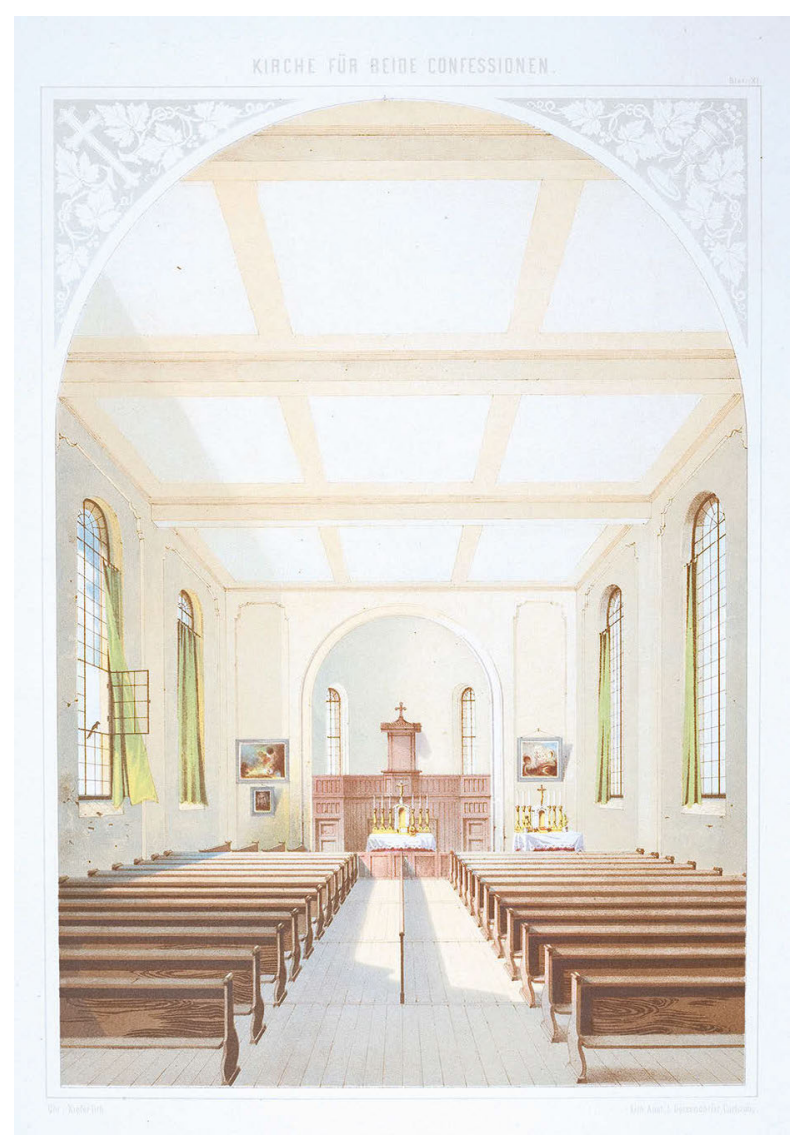

old, silence was social death. If the bell in the morning in the Illenau turned on the light in a sense, then now, "during the church service, solemn silence must reign in the whole institution" (Direction I865: 103). Only in silence is a connection to God established. Silence allows one to collect oneself (Jungwirth 1935/6; Kemmer 1986; Mensching/Hertzsch 1961; Wohlfart/Kreuzer 1992). And what is God's role here? He turns on the light. He is the light. And insanity is loss of "reason," the light that shines in us. This light has purposes: 
Reason was given to man, that he should be free from the compulsion of the laws of nature, that he should learn wisdom, recognize a god, be like him, that he should share in the bliss of immortal spirits. And he rejoices in this reason. He needs it to become ever better, more perfect and blessed. He proudly rises above the other creatures, but he does not forget that he may lose this divine gift, if only here in this time, and then sink lower than an animal can ever sink. (Roller I83I: VII)

Reason elevates us above nature, connects us with God. This materializes in the visual axis and church windows and presence in the room. Is this not also an optical reflection of order in the mentally ill via space? Spatial order makes light order. Light is not a medium of surveillance but of communication. It connects things and people with each other through gazes.

Again, how does the light fall on the institution in the morning? In figure II we see letters, the individual departments, the structure of the relatively connected sanatorium $^{6}$ : to the left, in the west, Pflegeanstalt (the section for long-term care); to the right, in the east, Heilanstalt (the section for treatable conditions). Men's department above, to the north, and women's department to the south. As for the natural light, neither part is given preference. The sun shines on the curable and incurable, on men and women. In the morning, the sun shines on the short-term care wing, and in the evening on the long-term care wing. The gender and the hopelessness of the disease are not reflected in architecture and light. Class differences also play no role in sunlight. The departments of the better-off are located in the middle facing the church. This makes no difference for the incidence of natural light.

Are there differences in lighting according to gender, class, or prognosis inside? Rooms were furnished differently according to the level of care (social class). For instance, in third class there was a bed, a chair, and a bedside table; in second class, straw chairs and blinds; in first class, patients could sit in an armchair, while retirees could relax on a sofa instead of an armchair; carpets were laid out in front of their beds (Direction I865: 22). (Did the carpets have a "friendly" color?)

Clearly, however, construction and light were based on the state of illness and behavior. In the case of the curable, three classes are distinguished according to social class: calm patients from the "upper classes," calm patients from the "second class, townspeople from the middle class," and calm patients from the "third class, farmers" (Roller I83I: 83). In manic, aggressive patients, "no difference in class is 
made. The manic baron, as long as he is manic, can be quite well located next to the manic farmer" (ibid.). Raving madness erases differences in class.

In the incurable, things were more complicated. Here class differences were in part ignored, and in part upheld. There was only one section for calm patients from the second and third classes: farmers and townspeople (from the middle class) were treated equally. A separate department was kept for the first class, because "not all incurables" are "imbecilic," meaning so deranged that they would no longer perceive the difference in class (ibid.). They still lived in rooms for the upper classes, where the furniture, colors, color play, and lighting conditions were maintained for them.

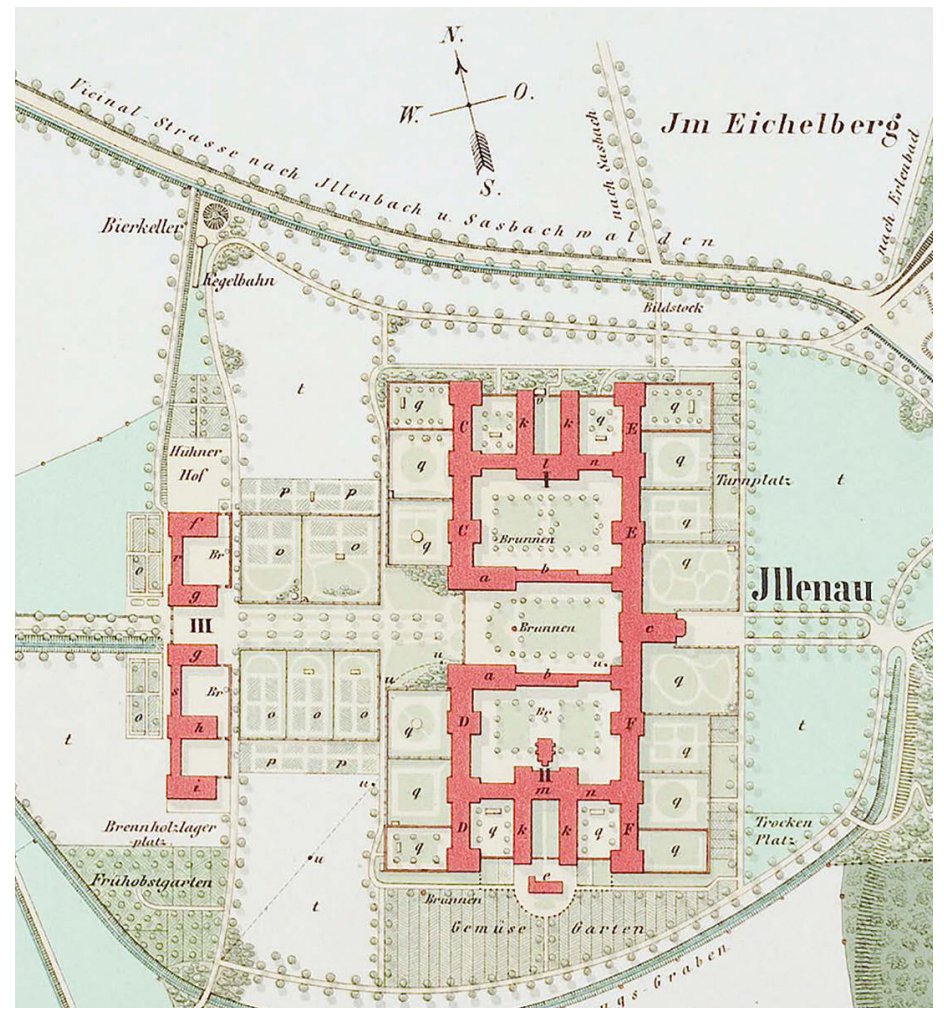




\section{Lellen.}

Langenschnit eines Zellengebaudes und des Luftheitzungsofens

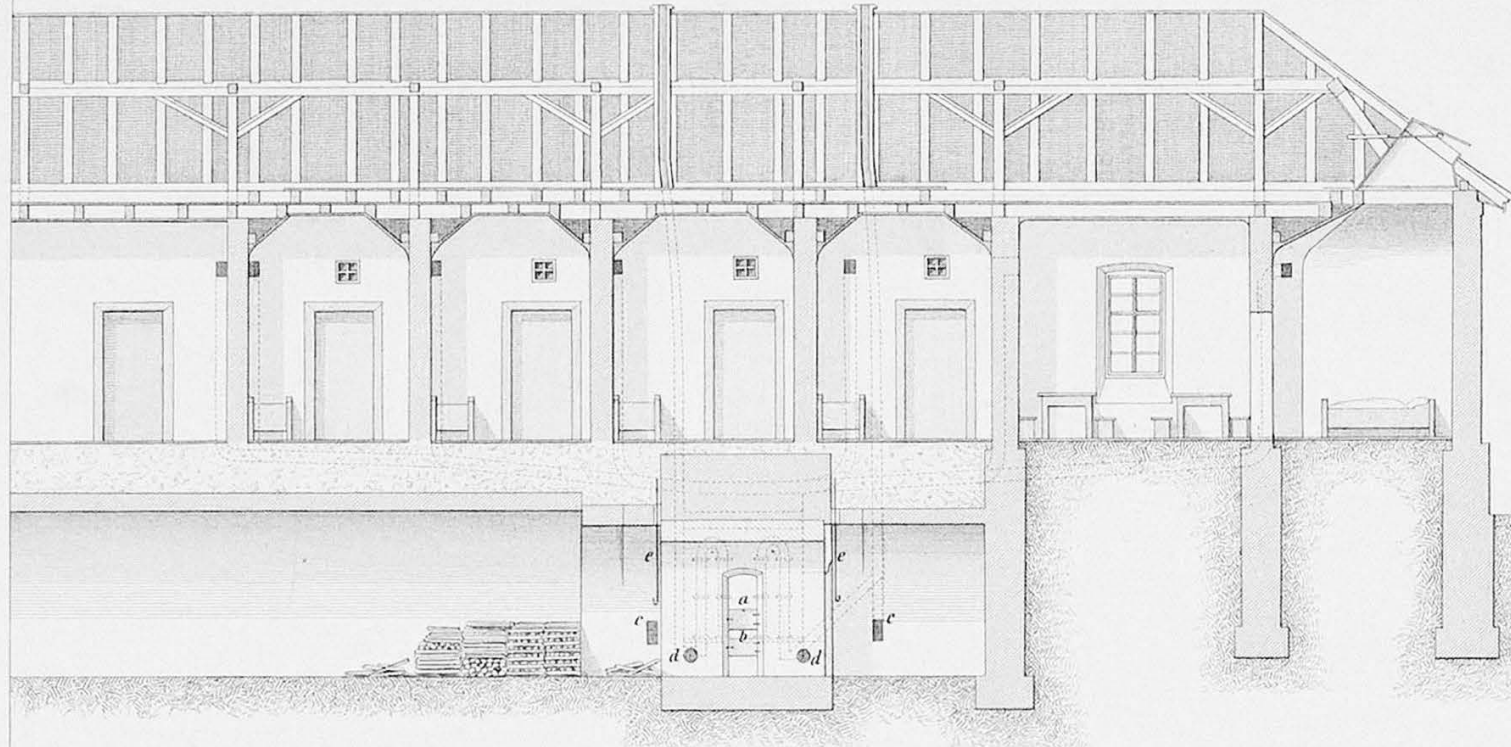

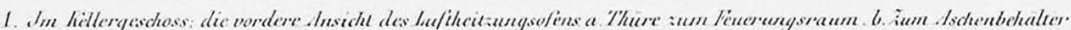

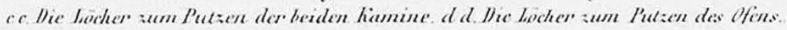

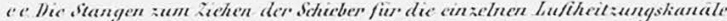

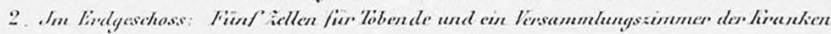

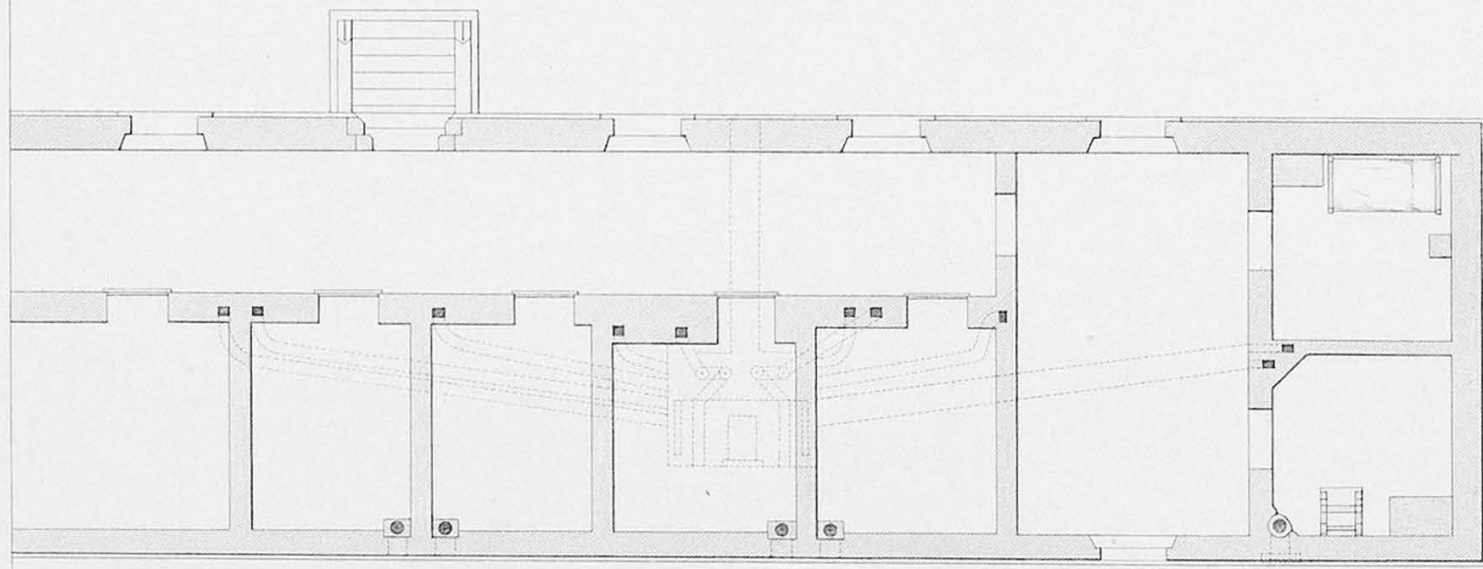

Fig. 12: Department for manic patients (from: Direction 1865)

> Fig. 13: Cell for manic patients (from: Direction 1865) 


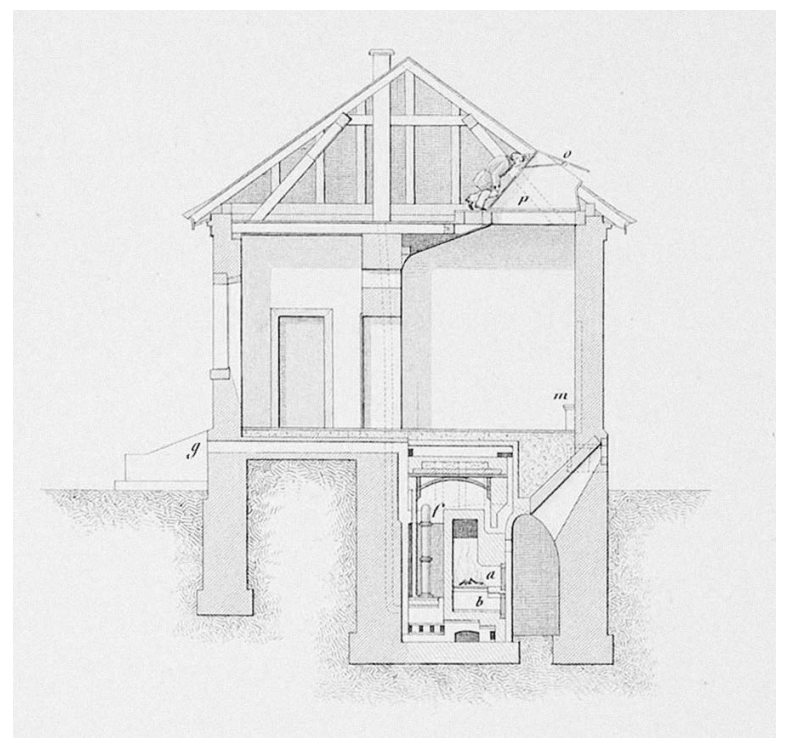

Let us examine the letters $\mathrm{K}$ in figure II - these are the areas for manic patients. They are spatially and visually constricted: the department for manic patients is one story tall (ibid.: 97), while the other departments are two stories tall. The cells receive little light. Their construction makes them even darker.

Consider figure I2 and I3: At the top left are five cells for manic patients, with high windows. The light can be mechanically regulated. The cells are dark; all light can be blocked out. Here no light flows; it is stopped, it is taken away or granted. Darkness is punishment and therapy (is it meant to create fear?). At the same time: "A prolonged detention" - meaning isolation - is a "sensitive punishment. It becomes even more so when the light is simultaneously taken away" (ibid.: 229-230). But it is not just about punishment, because "with darkness one also turns to silence" (ibid.). Silent darkness equals silence equals punishment equals peace equals pacifying. Manic patients alone in the dark - isn't that awful (see Freud's three-year-old)? 
Isolation, Light, and Communication

Isolation has positive connotations in the asylum. Patients must be isolated in an asylum; their ties to their family must be broken (ibid.: 3). Why? As will be shown, here light and communication/ties are brought together. After all, isolation is justified with reference to the place where the ties are broken, the family, and, secondly, with reference to the place where the isolation takes place: the asylum and in some cases in the asylum itself. Isolation in all three spatial dimensions was meant to prepare the patient for bonding and communication, and thus healing.

Mental illness means misunderstanding something in communication at home; mental illness is a communication disorder (ibid.: 4) as a bonding disorder: "What one says" to the patients "they understand in the wrong way or not at all and become impatient. Signs of the greatest tenderness they take for insults, or they seem to them like unsolvable riddles. The patients' mistrust grows, they become gloomy and fearful," and now the "most tender son, who found his greatest happiness close to his parents, in carrying out childhood duties, ... escapes from the family home" (ibid.). This is not meant as a cognitive disorder; it is the disorder of and fundamental damage to the patient's sociability: he becomes suspicious, breaks off communication and bonding. The words he exchanges with his family members no longer spread any truth in him. Dialogue as the basis of bonding and relationship is disturbed.

As mentioned, not only light and truth are closely related, but also speaking and light and truth (Bremer 1974). Etymologically, the connection between light and saying/revealing is deeply rooted in Indo-European languages. Saying is to make appear what has not yet appeared (Bechtel I879: I3I). In Greek, "shine and speak were originally one" (Curtius 1879). Why is saying the same as making appear? Because saying is "always a letting know" (Bremer 1974: 194); but knowing is based on seeing in Indo-European languages; thus, saying becomes "making to see and showing" (ibid.).

At home there is conversation. In the family, understanding, bonding through speech takes place. But the mentally ill person misunderstands. He is not illuminated, it does not become light, it becomes dark. He has to go to the asylum. There he is isolated. First he is bathed, then "he receives a refreshment and for a time is left to think about his new situation." Then: "During the initial period the patients remain in the rooms specially reserved for new arrivals," since the patient should not "immediately be brought into the varied company" of the other patients, and he must 
"be observed": "A device made for this purpose, but only invisible to the patients" - an observation window, a spyhole - would make sense here (Roller I83I: 273).

He is isolated in a room, is observed. This is the gaze of surveillance. But here, too, silence takes effect. He is left to himself, and so he is confronted with silence: "The first effect of isolation is that the new objects produce new impressions" (ibid.: 3). He is isolated - he receives the new impressions through optical laws through sight. The silence leads him to stop in his madness; the patient is meant to be able to collect himself, since now silence reigns, so that new impressions can penetrate into him. But voices have to appear again, so that the light of reason reappears in him. This is why, as was previously mentioned, the doctor's voice is so important in therapy. When he speaks, it becomes light. But also when he looks. It is advantageous if the doctor can impress by "his voice, his gaze" (ibid.: 317). Surely this gaze is also meant to banish madness, instill fear, tame the animal nature (through the light of reason):

[T] he first object of a physician, when he enters the cell, or chamber, of his deranged patient, should be, to catch his EYE, and look him out of countenance. The dread of the eye was early imposed upon every beast of the field. The tyger, the mad bull, and the enraged dog, all fly from it: now a man deprived of his reason partakes so much of the nature of those animals, that he is for the most part easily terrified, or composed, by the eye of a man who possesses his reason. (Rush I8I2: I75)

Originally, Roller said that the chief physician must be constantly present in the asylum, in constant contact with the patients (I83I: 32I). This proved impractical, since the Illenau was too large for the director to visit each and every patient on a daily basis, but he was meant to visit the four main departments (curable men, curable women, incurable men, incurable women), each of which was led by one doctor, at least "several times a week" (Direction I865: I2). He received the necessary information in the daily conferences. Communication and connection took place in conversations, in conferences. The department physicians were meant to be in close contact with the patients. ${ }^{7}$ Attendants were always present. They were responsible for the operative vocal business and maintained a bond with the patients. The higher-ranking attendants communicated with their superiors and were charged with "working on the individual patients" (ibid.: 30). Speaking can replace seeing. 
But there are also dangerous sights. The ailing do not belong in mental asylums; their sight is "not pleasing" - meaning not "inspiring trust" - to the mentally ill (Roller I83I: 8). Friendly sights create trust, like the colors of the clothes - connection through seeing. An unpleasant sight creates mistrust, and mistrust, in turn, as we saw in the example of the family, causes a communication disorder. But these visual axes are not only between people. Communication works through the institution itself: the interior and the exterior of the institution must be "calculated" for "inspiring trust," creating a bond, since trust is the "sacram anchoram of all psychic influence" (ibid.: I04).

Light creates a bond; it makes communication possible - but not all communication is allowed. For example, Roller is against teaching students in the asylum; relatives do not want to expose their sick "family members to the gazes of students," which would be embarrassing for them (ibid.: 37 ). It is about concealment/secrets, and so there are "improper" gazes. Outsiders are not allowed into the asylum: "The sanctuary for misfortune is desecrated by the gaze of curious onlookers" (ibid.). But is this just about shame? No. The gaze itself which falls on the patients, can be of different qualities: "women, children, and all non-scientifically educated men ... must be simply forbidden to enter the asylum" (ibid.: I73-I74) due to their lack of reason. "Improper" gazes must also be considered in the construction of the institution: It must not be on a mountain slope, where outsiders could look in from above (ibid.: 63).

But light cannot always be controlled. Roller is uncertain in his discussion of windows. Windows are a problem: they are transparent. Light can suddenly, uncontrollably penetrate into the interior - unless it is controlled as in the areas for manic patients. But there are techniques to control the light. What were the windows like from the inside? Were they like in figure 4 , the salon for ladies? The natural light is kept out somewhat; the curtains gently veil the outside.

And what about the corridor of the women's department in I9IO in figure 7 ? I already mentioned the straight light axis, but the incidence of natural light remains unclear in this picture. What was the relationship between windows and light at the Illenau? There is some information on this: "On each floor there can only be one row of rooms, all of which open to the corridor" (ibid.: I08). This had reasons related to lighting: otherwise it would be too dark in the corridor. 


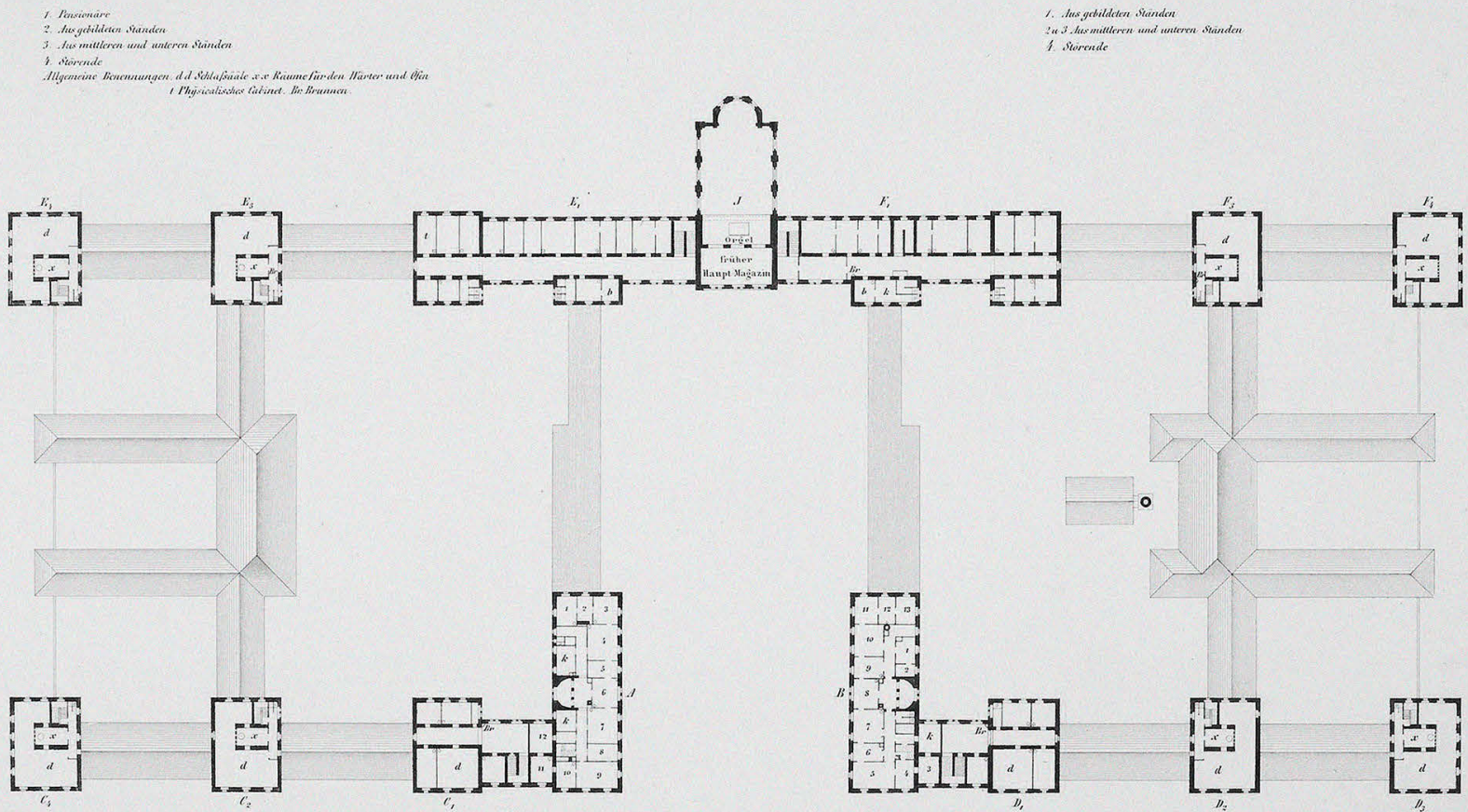

Figure I4 and I5 are views of the first floor of the men's side. In the detail view, the doors are not exactly parallel to the windows. There is no simple line of sight. Then we see the corridor. The aforementioned visual axis is broken at right angles. The rooms are at right angles to the main axis. But didn't Roller call for anything "angular" to be avoided? More precisely one must say: straight lines and right angles are allowed, but no other angles.

The patients should not be completely transparent. Living supervision must help, as the statute of 1852 specified: "The supervision must be complete; the patient must be observed in every place and at every hour, but in such a way that he is not too constrained and embittered" (quoted from Burkhardt 2003: 20I). 


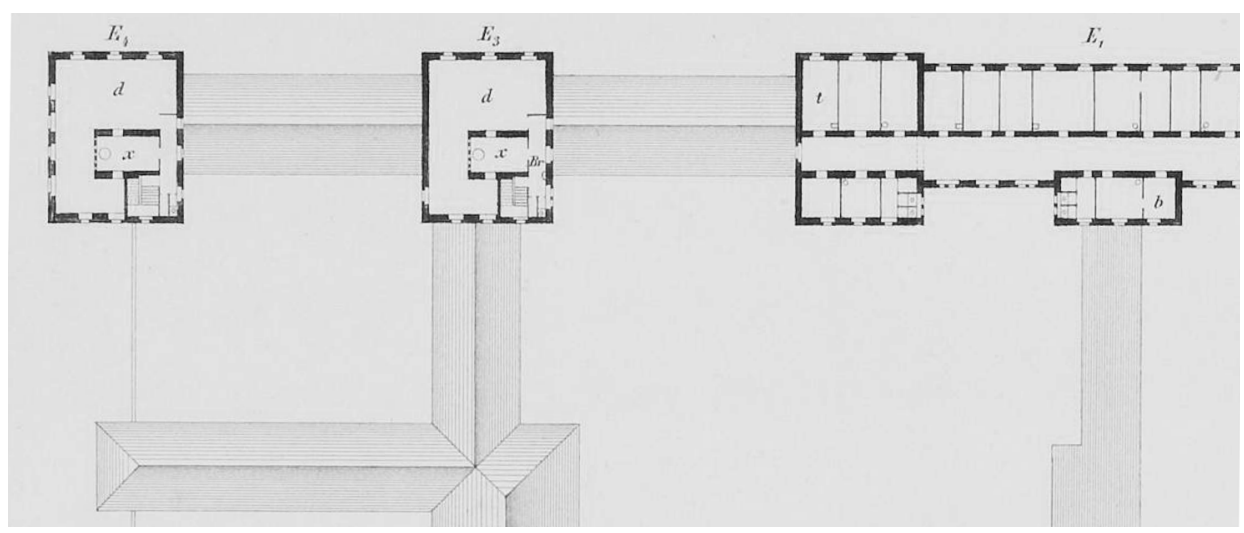

Summary and Conclusion

There are many things that I have only briefly touched on. A more detailed analysis would have to discuss architecture, metaphor, and intellectual history in a much more nuanced manner. However, some key concepts can be cited: (I) Light is a medium of communication; it connects people and things. (2) The construction of the asylum constructs lighting conditions through visual axes, outdoors through a specific arrangement of bushes, light, and space, among other things. The construction cannot address everything. Living supervision is important. (3) Sound and voice and silence have complex meanings in connection with light and dark. Sometimes it has to be quiet so that light or its night side, the dark, can take effect. But hearing and sound can replace seeing. (4) Constant physical presence would be important for communication and bonding. This is not possible. Talking in the asylum replaces the presence of the body. When someone speaks, it becomes light: we learned this from the statement by Freud's three-year-old boy. And now for the third excerpt from Bresson: If you replace "film" with "asylum" and add voice/ sound, then it reads: "Creating a mental asylum means connecting people to each other and to things through the gaze and the voice" (cf. Bresson 2007: 22). Then, one hopes, there is light in the dark auditorium or in the deranged mind. 


\section{Notes}

1

I can only rudimentarily discuss the history of the Illenau as a whole. Accounts of the Illenau and care for the mentally ill in Baden with different focuses include: Faulstich (1993); Beck (1983); Gehrke (1986); Kramer (1997); Löłsch (1996, 2000); Schneider (1981).

\section{2}

According to information from the director of the Achern city archive, Andrea Rumpf, on March 15, 2018.

\section{3}

I cannot dwell on the complex phenomenon of the "soundscape" of the asylum in full detail. But see for further information Kearin (2020); Fennelly (2014); MacKinnon (2003).

\section{4}

For instance, in the fifth century, the Roman prefect Cassiodorus described the functions of the night watches, quoted from Fischer (2015: 69).

\section{5}

Roller quoted in the original; the translation is my own: "on n'a pas une véritable instruction sur l'alimentation mental, si l'on n'a souvent observé les aliénés pendant la nuit."

\section{6}

A "relatively connected sanatorium" referred to a concept that was meant to supplant the previously propagated spatial separation of such institutions in the second phase of German psychiatry around 1830, see Damerow (1840).

\section{7}

The fact that even the department doctors were barely present for patients is illustrated by a case from the year 1875 in which a patient complains that the department doctor spends barely fifteen minutes in the department because he is too busy (Burkhardt 2003: 208).

\section{Bibliography}

Bechtel, Friedrich (1879): Über die Bezeichnungen der sinnlichen Wahrnehmungen in den indogermanischen Sprachen, Weimar: Böhlau.

Beck, Clemens (1983): Die Heil- und Pflegeanstalt Illenau unter C.F.W. Roller, dissertation med., Freiburg im Breisgau.

Beierwaltes, Walter (1980): "Lichtmetaphysik." In: Ritter, Joachim/Gründer, Kalfried (eds.): Historisches Wörterbuch der Philosophie, vol. 5, Darmstadt: Wissenschaftliche Buchgesellschaft, col. 289.

Beierwaltes, Walter/Bormann, C., von, (1980): "Licht." In: Ritter, Joachim/Gründer, Karlfried (eds.): Historisches Wörterbuch der Philosophie, vol. 5, Darmstadt: Wissenschaftliche Buchgesellschaft, col. 282-289.

Bremer, Dieter (1974): "Licht als universales Darstellungsmedium." In: Archiv für Begriffsgeschichte 18, pp. 185-206.

Bresson, Robert (2007 [1971]): Noten zum Kinematographen (edited by Robert Fischer), Berlin: Alexander Verlag.

Burkhardt, Marga Maria (2003): Krank im Kopf: Patienten-Geschichten der Heil- und Pflegeanstalt Illenau I842-I889, dissertation med., Freiburg im Breisgau.

Curtius, Georg (1879): Grundzüge der griechischen Etymologie, Leipzig: Teubner.

Damerow, Heinrich Philipp August (1840): Ueber die relative Verbindung der Irren-Heil- und Pflege-Anstalten in historisch-kritischer, so wie in moralischer, wissenschaftlicher und administrativer Beziehung: Eine staatsarzneiwissenschaftliche Abhandlung, Leipzig: Wigand.

Direction der Großherzoglichen Heil- und Pflegeanstalt Illenau (1865) (ed.): Illenau: Geschichte, Bau, inneres Leben, Hausordnung, Bauaufwand und finanzielle Zustände der Anstalt, Karlsruhe: A. Bielefelds Hofbuchhandlung.

Derix, Simone/Gammerl, Benno/Reinecke, Christiane/Verheyen, Nina (2016): "Der Wert der Dinge: Zur Wirtschafts- und Sozialgeschichte der Materialitäten." In: Zeithistorische Forschungen 13, pp. 387-403. 
Faulstich, Heinz (1993): Von der Irrenfürsorge zur "Euthanasie". Geschichte der badischen Psychiatrie bis 1945, Freiburg im Breisgau: Lambertus.

Fennelly, Katherine (2014): "Out of sound, out of mind: noise control in early nineteenth-century lunatic asylums in England and Ireland." In: World Archaeology 43, pp. 416-430.

Fischer, Ernst Peter (2015): Durch die Nacht: Eine Naturgeschichte der Dunkelheit, Munich: Siedler. Foucault, Michel (1992 [1975]): Überwachen und Strafen: Die Geburt des Gefängnisses, 10th edition, Frankfurt am Main: Suhrkamp.

Freud, Sigmund (1942): Gesammelte Werke, vol. 5, London: Imago Publishing Co.

Gehrke, Wolfgang (1986): Die Reformanstalt Illenau und ihre Bedeutung für die badische Irrenfürsorge in der Ära Roller: eine psychiatriehistorische Studie anhand der Illenauer Krankengeschichten I826-I877, dissertation med., Freiburg im Breisgau.

Goffman, Erving (1961): Asylums: Essays on the social situation of mental patients and other inmates, New York: Anchor Books.

Jungwirth, H. (1935/6): "Schweigen." In: Bächtold-Stäubli, Hanns (ed.): Handwörterbuch des deutschen Aberglaubens, vol. 7, Berlin/Leipzig: De Gruyter, col. 1460-1470.

Kearin, Madeline Bourque (2020): "'As syllable from sound': the sonic dimensions of confinement at the State Hospital for the Insane at Worcester, Massachusetts." In: History of Psychiatry 31/1, pp. 67-82. Kemmer, A (1986): "Schweigen." In: Höfer, Josef/ Rahner, Karl (eds.): Lexikon für Theologie und Kirche, vol. 9, Freiburg im Breisgau: Herder, col. 540-541.

Klein, Andrea (2003): "Jede Kommunikation ist wie Kunst”: Die Sprache des Gartens, Würzburg: Königshausen \& Neumann.

Kramer, Cheryce (1997): The Psychiatry of Gemueth in a Biedermeier Asylum, dissertation, University of Chicago.

Latour, Bruno (2007 [2005]): Eine neue Soziologie für eine neue Gesellschaft: Einführung in die Akteur-Netzwerk-Theorie, Frankfurt am Main: Suhrkamp.
Lengning, Anke/Lüpschen, Nadine (2012): Bindung Munich/Basel: Ernst Reinhardt Verlag.

Lötsch, Gerhard (1996): Christian Roller und Ernst Fink: Die Anfänge von Illenau, Achern: Acheron Verlag.

Lötsch, Gerhard (2000): Von der Menschenwürde zum Lebensunwert: Die Geschichte der Illenau von I842 bis I94O, Kappelrodeck: Achertäler Verlag.

Löw, Martina (2001): Raumsoziologie, Frankfurt am Main: Suhrkamp.

Mackinnon, Dolly (2003): "Hearing madness': The soundscape of the asylum." In: Coleborne, Catharine/MacKinnon, Dolly (eds.): 'Madness' in Australia: Histories, heritage and the asylum, St. Lucia QLD Australia: The University of Queensland Press, pp. 73-82.

Mahir, Oscar (1846): Ueber Irren-Heilanstalten, Pflege und Behandlung der Geisteskranken nach den Principien der bewährtesten Irren-Aerzte Belgiens, Englands, Frankreichs und Deutschlands, Stuttgart/Tübingen: J.G. Cotta.

Mensching, Gustav/Hertzsch, Erich (1961): "Schweigen." In: Religion in Geschichte und Gegenwart, vol. 5, 3rd edition, Tübingen:J.C.B. Mohr, col. 1605-1606. Plato (1971): "Politeia." In: Eigler, Gunther (ed.): Plato. Werke in acht Bänden, vol. 4, Darmstadt: Wissenschaftliche Buchgesellschaft.

Porter, Roy (1991): Kleine Geschichte der Aufklärung, Berlin: Wagenbach.

Reed, Terence James (2012): Mehr Licht in Deutschland: Eine kleine Geschichte der Aufklärung, Munich: C.H. Beck.

Roller, Christian Friedrich Wilhelm (1831): Die Irrenanstalt nach allen ihren Beziehungen, Karlsruhe: Müllersche Hofbuchhandlung.

Rush, Benjamin (1812): Medical Inquiries and Observations upon the Diseases of the Mind, Philadelphia: Kimber \& Richardson.

Schivelbusch, Wolfgang (2004): Lichtblicke: Zur Geschichte der künstlichen Helligkeit im 19. Jahrhundert, Frankfurt am Main: Fischer.

Schneider, Hugo (1981): "Die ehemalige Heil- und Pflegeanstalt IIlenau." In: Die Ortenau 61, pp. 191-231. 
Schüle, Heinrich (1910): "Die Landesanstalt Illenau." In: Bresler, Johannes (ed.): Deutsche Heil- und Pflegeanstalten in Wort und Bild, vol. 1, Halle (Saale): Marhold, pp. 1-9.

Strauß, Bernhard (2014): Bindung, Gießen: Psychosozial-Verlag.

Wohlfart, Günter/Kreuzer, Johann (1992): "Schweigen, Stille." In: Ritter, Joachim/Gründer, Karlfried (eds.): Historisches Wörterbuch der Philosophie, vol. 8, Darmstadt: Wissenschaftliche Buchgesellschaft, col. 1483-1494.

All quotations originally in German were translated by Anthony DePasquale. 